\title{
Integration and Islamisation Program for Clinical Post Graduate Students in International Islamic University of Malaysia (IIUM)
}

Nazri Mohd Yusof

Kulliyyah of Medicine, International Islamic University Malaysia,Kuantan Campus.

\begin{abstract}
Integration and islamisation (INI) programmes for undergraduate medical students have been practiced, reviewed and published in many journals. However, there is only a dearth of study on the implementation of such a programme for postgraduate clinical students. Hence, there is a need to examine such a programme because of the different learning environment and characteristic of the students. The aim of this paper is to examine the existing clinical postgraduate programme at IIUM and attempts to improve the INI curriculum. Method: The study employs an analytical method and important factors for the development of the curriculum are analysed to come out with the objective, content, teaching methodology and assessment method suitable for the program. Result: The study identified the important factors that determine the curriculum to be the needs of National Health Service, the mission of the university, the requirement of the professional body and characteristic of the students. The study proposes that the objective of the program is to produce holistic orthopaedic surgeons who understand the belief of Muslim patients and is able to facilitate them in their ibadah and daily life as a Muslims. This is achieved through offering a course which consists of 4 main subjects on the principles of shariah which include the element of Islamic worldview, figh ibadah, figh muamalah and Islamic moral values with emphasis on issues related to medicine. The teaching method proposed is having regular seminars which consist of presentations and discussion of important concept in Islamic fiqh and followed by case study on figh issues related to Medicine. Finally, the students should be assessed from the case write up which they are required to submit before they can sit for the final professional exam. Conclusion: This improved program enables students to complete their study without compromising their duties to provide services at their respective hospitals.
\end{abstract}

KEYWORDS: integration, islamisation, curriculum, clinical post graduate

\section{INTRODUCTION}

There is a growing interest in applying Islamic principles in Malaysia as evidenced by the rapid growth of Islamic banking and finance which has been well accepted by Muslims and non- Muslims. Malaysia has developed into one of the biggest producer of halal products which also include pharmaceutical products and services. Similarly, in the medical perspective there is an increasing number of Ibadah-friendly hospitals that have been initiated by the government and private sector. Furthermore, many patients did not perform prayers during their hospitalisation because they feltuncomfortable, embarrassed and had a lack of knowledge about prayers for the sick. Therefore, it is imperative that the doctors and nurses who work in the hospital are trained on Islamic issues related to medicine to facilitate the patients' spiritual need. ${ }^{1}$

The integration and islamisation (INI) Programme for undergraduate medical students in IIUM has been established nearly two decades ago and has produced doctors that are not only competent in treating diseases but also excel in handling the

Nazri Mohd Yusof

Kulliyyah of Medicine,

International Islamic University Malaysia,

Kuantan Campus.

Email: nazriyusof@iium.edu.my psychological, social and spiritual needs of patients. ${ }^{2}$ However, the process of INI among clinical post graduate students is more challenging because the students spent most of their time providing clinical services to patients in their respective hospitals.

In order to instil Islamic principles and values to these students, the Department of Orthopaedic, Traumatology and Rehabilitation (DOTR), IIUM has developed the Application of Figh in Medicine course for its clinical post graduate students. The initial curriculum of the INI program does not take into account the differences in the environment and characteristics between the undergraduate and postgraduate clinical student. ${ }^{3}$

\section{Clinical post graduate program}

The clinical orthopaedic post graduate program in IIUM began in 2008 to fulfil the demand of the country to have orthopaedic surgeon ratio of $1: 25,000$ to the population. The program was developed based on the models of University Malaya, University Kebangsaan Malaysia and University Sains Malaysia which have started the program earlier. It also follows the recommendation from the Conjoint Board of Orthopaedic (CBO) that oversees orthopaedic training and run the orthopaedic professional examination in Malaysia. 
The board that was formed in 2003 consists of senior representatives from universities that run the orthopaedic training, Ministry of Health $(\mathrm{MOH})$ Malaysia, Malaysian Orthopaedic Association and the Academy of Medicine. ${ }^{4}$

The orthopaedic training programme aims to produce orthopaedic surgeon capable of providing general orthopaedic services in the public hospitals. This is in line with one of the strategic plan of Ministry of Health to provide accessible quality of service to the country. ${ }^{5}$

The clinical post graduate program is an apprentice fellowship program where the students are based in the public hospitals and are supervised by a mentor or supervisor. The mentors or supervisors who are appointed by the university are consultant orthopaedic surgeons in the public hospitals. Their role is to guide and monitor the trainees while they are providing services in the orthopaedic clinics, wards and during the operations.

Besides providing services, the trainees are also required to conduct research which begins in their second year of study. The completed research or dissertation is submitted before they appear for their final professional examination in year four.

\section{The IIUM mission}

Besides providing orthopaedic specialist training, IIUM has a mission to integrate and incorporate Islamic values and perspective in its education program. With that in mind, the DOTR has developed its own programme to INI clinical post graduate programme which is different from their undergraduate counterpart.

\section{MATERIALS AND METHODS}

This is an analytical study to develop the INI curriculum for orthopaedic clinical post graduate students in IIUM. We believe, the curriculum can also be applied for other clinical post graduate programmes that have a similar structure.

\section{Development of curriculum}

The curriculum has four major areas which are the philosophy or the objective of the program, the content or scope of knowledge, the methods of delivering or construction of the knowledge and the method of assessing the learning process for achievement of the objectives. ${ }^{3}$

During the initial period of its establishment, there were no specific programs for the post graduate students. They only joined the Islamic Input in Orthopaedic (IIIO) program which is a oneday program for the undergraduate students. The program which has started in 2002 is an interactive program which consists of problem based case discussion and practical simulation. ${ }^{7,8}$ However this program is not sufficient for the post graduate students because they do not have enough background of Islamic Science knowledge like the undergraduate students. The undergraduate students have undergone the IIMP before they enrolled for the orthopaedic posting at year four.

\section{The objective (philosophy)}

The objectives of the program were adopted from the Islamic input in Medical program (IIMP) which is the INI that were incorporated for the undergraduate medical program of the Kulliyyah of Medicine IIUM since its inception in 1997. 2,6
IIMP (undergraduate)

To introduce Islamic perspectives related to medicine

To strengthen faith through study of Allah's signs in the human body

To understand the jurisdical and fiqh issues related to medicine

To understand the social issues related to medical practice and research
Application of figh in medicine (post graduate)

To apply a holistic approach of patient care.

To expose students on the elements of Islamic worldview and its application in health and illness.

To educate students on the figh principles and its application in health and illness.

To enhance professionalism, ethics and physician etiquette by inculcating spiritual values

To inculcate professional etiquette from the Islamic perspective

The first objective of this program is for the trainees to view patient not just as a person with a disease but as a complete human being with feelings, beliefs and families. The family takes care of them during their illnesses and is also dependent on them as a breadwinner. Sometimes, taking care of the patients also affects their job performance resulting in frequent absenteeism. This is in line with medical professions duty to treat a patient as a person and not as a disease.
The second objective is for them to understand what goes inside the mind of Muslim patients when they are contracted with calamity or a disease. It also helps them to differentiate between the true Islamic teaching or local customs and beliefs that were practiced by their patients.

The third objective is to understand the difficulties of Muslim patients to perform their religious and social obligation during their illnesses. They are 
introduced to the principles in fiqh to help them understand the issues and suggest the solution for the patients' problem.

The last objective is to train the trainees to become the specialist with professionalism and integrity by inculcating Islamic values such as sincerity and doing the best for the patients.

\section{The content}

The program is divided into 4 main theme or scopes:

\section{Muslim belief system. Theme understanding Muslim patients}

A- Islamic worldview and the concept of unity tauhid A:1 .discussion about illness and its relation to faith

B- Iman - believes in Allah, the Holy Books, the angels, the prophet, the Hereafter

$\mathrm{B}: 1$.discussion about quran and hadith as sources of knowledge

$\mathrm{B}: 2$.discussion about scientific facts and others related to medicine in the quran

\section{C.Qadha and qadar}

$\mathrm{C}: 1$.discussion about fate and the importance of Qadha and Qadar, and

C:2 .counselling skills toward patients

D.Life, illness and death

D: 1 .Discuss about humans as a biological, psychological, spiritual and a social being $\mathrm{D}: 2$. The inevitability of death and the promised rewards for patience and redha.

\section{E.Effort and tawakkul}

E:1.discussion about Allah as the curer for all diseases

E:2.seeking hard for a cure for all diseases, and $\mathrm{E}: 3$. the importance of dua

F.Beliefs on causes of disease and alternative medicine

$\mathrm{F}: 1$.discussion about sihr

F:2.discussion on mental illness and psychosomatic illness

G.Islamic medicine

2.Fiqh ibadah. Theme facilitating Muslim patients

A: Maqasid al-shariah

A:1 .discussion about the source of figh (Usul fiqh)

$A: 2$.discussion on the purpose of law
B:Qawaid Syariah - legal maxim

$\mathrm{B}: 1$. Discussion about the principles of law

$\mathrm{B}: 2$.discussion on its application in health

\section{C.Rukhsah}

C:1.discussion about exception of law granted to preserve life and remove hardship

D.Cleanliness, purification and ablution

D:1discussion on how it is affected by disease and what is the possible solution

E.Prayer, fasting, hajj

$\mathrm{E}: 1$.discussion on how it is affected by disease and what is the possible solution

F.Contemporary issues in health

3.Figh muamalah Theme social effect of disease and solution in Islamic perspective

A.Zakat/ sadakah/ waqaf

A:1.discussion on Islam's methods to care for the welfare of the poor and the society

\section{B.Contract / service}

$\mathrm{B}: 1$ discussion about the duties of doctors and the rights of patients

C.social issues related to health (affected or cause by disease)

D. Marriage/ premarital pregnancy / abortion

E.Inheritance

F.Compensation

G.Takaful

H.The Muslim Society

I.Importance of research to the society

4.Medical ethics and akhlaq in Islam -Theme the ideal doctors

A.Foundation of Islamic moral system

1.Ikhlas

2. Taqwa

3. Amanah

4.Ihsan

5.Compassionate

B.Work as ibadah

B:1.Discussion on the scope of ibadah

C.Professionalism

D.Common issues brought to medical inquiries 
D:1.Negligence

D:2.Consent
E.Research ethics

\section{Teaching methods}

After the curriculum review and brainstorming exercise in January 2011, the department has decided to run a once yearly course. The program takes into account of the special characteristics of the clinical post graduate student which are:

\section{-Adult learners' age $>32$ years old}

- The students are trained and registered doctors with at least 3 years' experience as a medical officer. They have good background knowledge in general medicine.

\section{-Practicing medical professionals}

-The students are young doctors who run the services for inpatient and outpatient in the department. They cannot be out of the department for a long duration to avoid disruption of service in the hospital.

-Practice in other hospital

-The students are posted in public hospitals that are gazetted as a training centre and supervised by consultant orthopaedic surgeons

-Different baseline knowledge of Islam

-The students are from different ethnic group and religious background. A few are alumni of IIUM medical faculty who have gone through the five years of IIMP.

With that in mind, the department believes a more focused, interactive, experience sharing and application of knowledge relevance to their clinical practice is more suitable for the students. This is in line with the adult learning theory as proposed by Knowles MS. ${ }^{9}$

There are four proposed seminars in the program as follows:

1.Seminar of Islamic worldview in medical practice 2.Seminar of figh ibadah in medicine 3.Seminar of fiqh muamalah in medicine 4.Seminar of Islamic medical ethics

The seminar begins with lectures by an Islamic Science scholar to be followed by a case discussion or group discussion on issues that are related to patients care. Specialists from other disciplines are also invited to share their experience in applying Islamic principles and values in a multidisciplinary care approach.

\section{The seminar}

1.Islamic worldview in medical practice The facilitator should be from among the psychiatrists, psychologists, or traditional practitioners
A:1.Islamic worldview

A:2.Illness and faith

B.Application and discussion of concept (case discussion)

B:1.Dealing with patients who believes in supernatural powers

B:2.Dealing with patient with unwanted pregnancy and requesting for an abortion

\section{Fiqh Ibadah}

The facilitator should be from Islamic Revealed Knowledge and Human Science (IRKHS)

A.Introduction of the concept (lecture)

$A: 1$. The purpose of shari 'ah

A:2. Islamic legal maximA

A:3.Rukhsah (relief or concession)

\section{B.Application and discussion of concept} (case discussion)

$B: 1$. Prayers during illness

B:2.Fasting and illness

B:3.Pilgrimage for ill patients

Fiqh muamalat

The facilitators should be from IRKHS and Medical faculty

\section{A.Introduction of concept (lecture)}

A:1.Figh muamalat

A:2.Social implication of illness/ disability

B.Application and discussion of concept (case discussion)

B:1.Premarital pregnancy

B:2.Inability performing duties

B:3.Social support

B:4. Health service model

4. Islamic medical ethics

The facilitator should be from among the dean of the Medical faculty, members of Malaysia Medical Council, IRKHS

A.Introduction of the concept (lecture) A:1.Medical ethics and professionalism A:2.Medical negligence

\section{B.Application and discussion of concept} (case discussion)

$\mathrm{B}: 1$.Values of a good doctors from non-medical personnel perspective

B:2.Non ethical conducts brought to Medical council

B:3.Professionalism in medical practice 
Students are required to submit one case write up at the end of the program on issues related to Islam and medical illness. Examples of case write up topics that has been submitted include:

1. Medical ethics in multicultural country: differences in principles and practices among Muslims and Buddhist patients

2.Approach to Muslim orthopaedic surgeons by a non-Muslim doctor

3.Performance of prayers for patients with diabetic ulcer

4.A brief comparison on Islamic and Ayurveda medical principles

5.Dying, end of life and death in Islam

6.Implementing da'wah among orthopaedic patients

7. Helping a patient to perform ibadah in the ward:

the role of the health personnel

8.Smoking from an Islamic perspective

9.Performance of prayers for total knee

replacement patients

10. Islamic medical ethics in orthopaedic

11.Counselling patients for amputation according to Islamic perspective

\section{DISCUSSION}

There are several challenges in producing an effective and efficient INI curriculum for clinical post graduate students. These challenges include the

1.Lack of measurable objective

2.Lack of knowledge in Islamic curriculum

foundation

3.Lack of competent teachers with professional and Islamic knowledge

4. Lack of teachers' knowledge in teaching

methodology and assessment

5.Lack of textbook and reference material

In order to develop a good INI curriculum for clinical post graduate students it requires a conjoint effort of a medical practitioner, an Islamic scholar and an educationalist. This curriculum is still in the developing stage and it has a lot of rooms for improvement in the methods of delivery and assessment of the student. Research on the outcome and effectiveness of this program would allow for the identification of the weaknesses and areas for improvement.

The seminar allows group discussion, exchange of ideas and observation of students' attitudes and behaviours be observed. By calling the students back to the university it allows the lecturer to interact, monitor their student performance and receive feedback from them. The guest speaker from among the practicing medical psychologist, the traditional Islamic practitioners and council members of the medical council can expose the students to the application of the knowledge in real life practice.

The instructors also need to be trained to become the role model as doctors who practice Islam in their daily work in the hospital. They can give advice to patients and teach Islamic medical practice in the wards, clinic or operation theatres. ${ }^{2}$ The opening of the IIUM Medical centre in 2016 will hopefully improve the learning environment of students about Islamic Medical Practice.

The assessment method can be improved so that it can assess all the intended objectives of the program. The case write up will enable the students to go into the depth on certain topics or problems of their interest that are related to Islamic medicine. Their thinking process and methods to derive solution of patients' problem based on the fiqh principles can also be assessed.

\section{CONCLUSION}

The process of INI of knowledge in post graduate clinical students can only be concluded with the publication of a textbook that integrates Islamic values and concepts with medicine and having trainers who are competent both in Medicine and Islamic teaching.

\section{ACKNOWLEDGEMENT}

I would like to thank Prof Dr Rosnani Hashim from the Kulliyyah of Education (KOED), IIUM for her guidance on the writing of this article.

\section{REFERENCES}

1. Suhaiza A, Hamizah I, Mazira CH, Aidil AR, Mustafa KB, Zalina N, Ziana AW. 2013.

Knowledge, perception and attitude among pregnant mothers towards ibadah. Int Medical $\mathrm{J}$ of Malaysia. 12(S2)

2. Osman A. 2016.Islamic input in medical program: A realization of a holistic medical education. $J$ of Education and social sciences.4:147-153

3. Hashim R. 2013. Higher education curriculum development for islamization of knowledge. Islamic economics education in southeast Asian universities:51-73. Centre for Islamic Economics, IIUM, Kuala Lumpur and International Institute of Islamic Thought, Herndon, VA 20170 USA

4. Ibrahim S. 2011. Editorial. Postgraduate orthopaedic training 1981-2010: Thirty years of the Masters programme in Malaysia. Malaysian Orthopaedic Journal.5:1-3

5. Ministry of health Malaysia Strategic plan 20062010. April 2008

6. Omar Hasan Kasule. Islamization of the curriculum: the Islamic input in medical curriculum (IIMC) at the kulliyah of medicine. Paper presented at the Ibn Sina Medical College Dhakka Bangladesh on the $31^{\text {st }}$ March 2007

7. Mohd Ariff Sharifudin, Mohd Adham Shah Ayeop, Aminudin Che Ahmad. Implementation of the Islamic input in Orthopaedics (IIIO) undergraduate medical curricula and practice: IIUM's experience (2002-2014). Revelation and science in the $21^{\text {st }}$ century. Page 141-148

8. Hafiz A, Nazri MY, Khalid KA, Aminuddin CA, 
Zamzuri Z, Yusof A, Azril A, Shukrimi A (2004). Practical Islamic Input in Orthopaedics

Undergarduate Medical Curricula.. Int Med J; $3(2)$

9. Malcolm S Knowles.(1980) What is Androgogy. The Modern practice of adult education. From pedogogy to androgogy. Cambridge Adult Education.Prentice Hall Regents. Englewood Cliffs, NJ 07632: 40- 59 